\title{
Remnants of Information Privacy in the Modern Surveillance State
}

\author{
LAWRENCE FRIEDMAN* \\ "Information is all, is it not?"1
}

\section{$\mathrm{T}$}

ake as a given that we must, in the interest of national security, gather intelligence about potential foreign threats. As Laura Donohue observes on the first page of The Future of Foreign Intelligence: Privacy and Surveillance in a Digital Age, presidents have authorized foreign intelligence collection since the earliest days of the republic. ${ }^{2}$ The question today is not whether to acquire foreign intelligence, but how to go about it. Part of the answer depends upon what is technologically and practically feasible, and part upon what is legally permissible. And the legal limits confound us: as Donohue explains, what national security demands-or, at least, what our elected leaders and the national security establishment often believe it demands-seems frequently to run counter to the Fourth Amendment's commitment to the protection of information privacy from random government snooping.

Indeed, the reality of foreign intelligence collection in the digital age is that the Fourth Amendment doctrine, as interpreted and applied by the courts, trails both operational needs and executive assurances about the breadth of the surveillance undertaken and its potential impact on privacy. To be sure, many Americans, even if confronted with the actual scope of the government's surveillance efforts - which may, as Donohue notes, capture personal information about many thousands of United States persons-likely would express a preference for security over privacy, as if the two values necessarily stood in opposition to one another. And many

* Professor of Law, New England Law I Boston. My thanks to New England Law Review editor-in-chief Alison Shea, for her research assistance and patience; and to my colleague Vic Hansen, for his thoughts and comments.

1 Said to James Bond by the villainous character Ernst Stavro Blofeld in the film Spectre. SPECTRE (Eon Prods. 2015).

2 Laura Donohue, The Future of Foreign InTElligence: Privacy AND SurVeillance in A Digital Age 1 (Oxford 2016). 
likely would acknowledge that they trust executive department actors to conduct such surveillance responsibly. And even those who might question the basis for such trust likely would hold close the beliefnotwithstanding the real possibility that they too blithely share all manner of information about themselves through electronic means - that inevitably it will be the details of someone else's life the government captures and exploits.

Of course, the framers of the Fourth Amendment-and the framers of the similar state constitutional provisions that preceded it-chose not to rely upon trust. Recall that agents of the Crown in pre-Revolutionary days employed general warrants to conduct searches of almost anyone or anything, and for almost any reason. ${ }^{3}$ Having been the targets of these searches, the framers had few illusions about whose privacy the government was likely to invade, and why. ${ }^{4}$ In this light, the information privacy protected by the Fourth Amendment can be understood to have a political dimension-as necessary to secure a space in which individuals may criticize their government's leaders and policies without fear of arbitrary invasion by that same government. ${ }^{5}$ In that space, the people may compose and save their critical or dissenting thoughts in their "papers" and "effects" - today, their smartphones, personal digital assistants, and electronic notebooks. As Justice Lewis Powell observed long before the dawn of the internet, "private dissent, no less than open public discourse, is essential to our free society." 6

In addition to its political dimension, the protection of privacy from arbitrary governmental invasion allows us, as Donohue puts it, "to pursue our own values, without others limiting our thoughts, actions, and perceptions, [which] is central to our ability to define ourselves. It matters for our personal and moral development." 7 The ability to define ourselves would be circumscribed if we lacked control over the information that formed the definition. ${ }^{8}$ Surveillance marks a loss of control-that is its

\footnotetext{
${ }^{3}$ Id. at 75.

4 See United States v. Verdugo-Urquidez, 494 U.S. 259, 266 (1990) (discussing hostility of former colonists to "general search warrants permitting the search of private houses, often to uncover papers that might be used to convict persons of libel"); Silas J. Wasserstrom, The Incredible Shrinking Fourth Amendment, 21 AM. CRIM. L. ReV. 257, 287 (1984) (discussing the role of Fourth Amendment as "intended to protect the right of people to be secure by ensuring that governmental power would remain subject to judicial control").

5 See DONOHUE, supra note 2, at 101 (arguing that privacy "is critical for our political engagement"); see also Thomas P. Crocker, The Political Fourth Amendment, 88 WASH. U. L. ReV. 303, 311 (2010) (discussing the role of the Fourth Amendment in protecting political liberty).

6 United States v. U.S. Dist. Court, 407 U.S. 297, 314 (1972).

7 DONOHUE, supra note 2, at 101.

8 See DONOHUE, supra note 2, at 102.
} 
point-and the prospect of surveillance, Donohue argues, may cause individuals to "change their behavior in ways that hurt social interaction and the ability ... to build strong relationships." 9

In view of information privacy's importance, it would be passing strange simply to entrust its protection to the discretion of the executive branch. And yet, as Donohue contends in The Future of Foreign Intelligence, the Foreign Intelligence Surveillance Act (FISA) ${ }^{10}$ effectively allows the government to capture and store the communications of U.S. persons while it is engaged in foreign intelligence surveillance. ${ }^{11}$ Indeed, under rules put in place in the last days of the Obama administration, more than a dozen intelligence agencies may now have access to, and search directly, much of the raw data collected by the National Security Agency (NSA) under various surveillance programs. ${ }^{12}$ The analysts at these agencies do not have to justify requests to access and search the raw data under any legal standard that reflects the requirements of the Fourth Amendment-no showing of individualized suspicion, no determination of need by a neutral and detached magistrate. None of these analysts are directly accountable to the people for their actions. We just have to trust that they are acting in good faith.

Congress, when it enacted FISA, simply did not contemplate the ubiquity of electronic communication, or that a great deal of information about U.S. persons would be scooped up through foreign intelligence surveillance. ${ }^{13}$ Section 215 of FISA allows the government to collect "tangible things," which successive administrations have defined to include information about Americans in the control of such entities as telecommunications service providers (among others). ${ }^{14}$ The information captured includes internet and telephony metadata-the information, Donohue correctly notes, that "provides the context for everything we $\mathrm{do}^{\prime 15}$ - and, sometimes, the contents of communications. Once acquired in the name of foreign intelligence gathering, much of the information may then be made available for use by U.S. law enforcement agencies-without those agencies having to comply with the Fourth Amendment, as they

\footnotetext{
9 DONOHUE, supra note 2, at 103.

1050 U.S.C. $\S 1801$ (2015).

11 See DONOHUE, supra note 2, at 151-52.

12 Charlie Savage, N.S.A. Gets More Latitude to Share Intercepted Communications, N.Y. TIMES (Jan. 12, 2017), https://perma.cc/94GB-3KY6.

13 See Benjamin Wittes, LaW AND the LONG WaR: The Future OF Justice IN the Age of TERROR 222 (2008) (observing that "the communications and data infrastructure FISA sought to regulate no longer exists and the one that exists today was beyond the fathoming of legislators thirty years ago").

14 See 50 U.S.C. $\S 1861$ (2017).

15 DONOHUE, supra note 2 , at 39.
} 
would if they sought this information on their own. ${ }^{16}$

The practice of foreign intelligence surveillance, in short, has evolved to escape ordinary Fourth Amendment analysis. Donohue contextualizes the problem by reference to the orders issued by the Foreign Intelligence Surveillance Court (FISC) that allow the bulk collection of metadata. These orders, she argues, are

strikingly similar to the general warrants that caused the Founders concern. It would be difficult to imagine a better example of a general warrant, than the one order, issued by FISC, authorizing the collection of international Internet and telephone content. It names approximately 90,000 targets, in the process monitoring millions of Americans' communications. The order is not premised upon prior suspicion of wrongdoing. It does not identify a particular place to be searched. The program is so massive that the government admits it is impossible to state the number of citizens whose e-mails, telephone conversations, visual communications, and private documents are being monitored. ${ }^{17}$

What is to be done? Donohue urges changes to the way in which the FISC operates-for example, by giving that court an expert advisory panel, to "decrease [its] reliance on the intelligence agencies,"18 and by rule changes that would allow for the possibility of adversarial argument and appeal from FISC orders, ultimately to the U.S. Supreme Court. ${ }^{19}$ She suggests we need to restore the line separating national security information from information relating to criminal activity-a line undermined by the 2002 ruling by the Foreign Intelligence Surveillance Court of Review in In re Sealed Case. ${ }^{20}$ Perhaps most importantly, she advocates for "a new constitutional rule of construction that acknowledges the deeper privacy interests involved." 21 At a minimum, she believes we need "a new Fourth Amendment test" that, among other things, "recognize[s] the rejection of general warrants that marked the Founding." 22

Legislative reform would be welcome, and recent history shows it may be possible. ${ }^{23}$ But there is a reason the framers sought to constitutionalize

\footnotetext{
16 See DONOHUE, supra note 2, at 74.

17 DONOHUE, supra note 2, at 95.

18 DONOHUE, supra note 2, at 144.

19 See DONOHUE, supra note 2, at 145-46.

20 See generally In re Sealed Case, 310 F.3d 717 (FISA Ct. Rev. 2002).

21 DONOHUE, supra note 2, at 157-58.

22 DONOHUE, supra note 2, at 157.

23 See LAWRENCE FRIEDMAN, National Security in the United States Through a Litigation Lens, in Routledge HANDBOOK OF DEMOCRACY AND SECURITY (forthcoming 2019) (discussing
} 
the protection of information privacy. The strength of legislative oversight necessarily depends upon the seriousness with which those members of Congress assigned the responsibility go about their task. Though meaningful oversight may become a routine practice and expectation, motivated members of Congress can undermine even long-settled accommodations. ${ }^{24}$ Foreign intelligence collection, moreover, is complicated and, of necessity, secret, which advantages the executive in its reports to members of Congress; one result is that policies designed and executed by the intelligence agencies gradually become effectively immune to the changes of direction often associated with the election of a new administration. ${ }^{25}$

The uncertainty of legislative oversight points to the importance of judicial enforcement of the privacy norms embedded in the Fourth Amendment, and it is difficult to disagree with Donohue's central conclusion that, to recalibrate the balance between security and privacy, we need a new and enforceable understanding of the Fourth Amendment's reach in the area of foreign intelligence collection. But such an understanding can only come from the U.S. Supreme Court-and it's likely not coming soon. There are at least two reasons why: first, the value of information privacy has been diminished over the past several decades, as the Supreme Court has favored governmental over individual interests when interpreting and applying the Fourth Amendment. Second, the Court's institutional deference to the political branches in matters touching on national security suggests the justices would be reluctant to risk the Court's institutional standing on privacy protection. I address each of these reasons in turn.

\section{The Problem of Precedent}

The Supreme Court's failure to understand or contextualize rapid developments in communications technology has effectively diminished

congressional control over collection of telephony metadata).

24 Cf. Lawrence Friedman, The Ninth Justice, NeW ENG. L. Rev. FACUlTy Blog (Apr. 8, 2016), https://perma.cc/9BG8-97B8 (discussing the decision of Senate Republicans to ignore constitutional text and tradition by refusing to hold hearings on President's nominee for open U.S. Supreme Court seat).

25 See Michael V. Hayden, Donald Trump Is Undermining Intelligence Gathering, N.Y. TIMES (Mar. 9, 2017), https://perma.cc/Q5VY-KHTQ (discussing apolitical professionalism of intelligence agency personnel); see also Michael J. GLENNON, NATIONAL SECURITY AND DOUBLE GOVERNMENT 6 (2015) (explaining that control over national security policy in the United States lies with the network of "several hundred executive officials who sit atop the military, intelligence, diplomatic, and law enforcement departments and agencies that have as their mission the protection of America's ... security"). 
the constitutional scope of information privacy. The weight of the resulting precedent has, as one commentator observed, put privacy "on life support," 26 a condition that is merely the logical extension of cases decided long before the digital connectivity we enjoy today became commonplace. For example, the reasonable expectation of privacy test-used by courts to determine whether an individual has any protectable privacy interest under the Fourth Amendment-and the reasonableness test-used by courts to determine the validity of a search (assuming the existence of a protectable privacy interest)-have created doctrinal obstacles to the realization of the reforms for which Donohue advocates in The Future of Foreign Intelligence.

Consider, first, the effect of the third-party doctrine on the reasonable expectation of privacy test. This doctrine, developed by the Supreme Court in the late 1970s, holds that individuals have no reasonable expectation of privacy in information they voluntarily transmit to third parties, like financial institutions and telephone service providers. ${ }^{27}$ If you have no continuing expectation of privacy in information you disclosed to someone else, that information will no longer be considered protected from acquisition by the government under the Fourth Amendment.

As Donohue notes, in the digital age the third-party doctrine effectively renders unprotected, for Fourth Amendment purposes, much of the information about our lives that we routinely create and share through various digital platforms. ${ }^{28}$ In American Civil Liberties Union v. Clapper-a challenge to the NSA's collection of telephony metadata in the service of foreign intelligence acquisition-the District Court recognized that this information, "[i]f plumbed, ... can reveal a rich profile of every individual as well as a comprehensive record of people's associations with one another." 29 The Court nonetheless concluded that, under the third-party doctrine, the voluntary disclosure of the information that constitutes metadata eliminates any reasonable expectation of privacy in it. ${ }^{30}$ The third-party calculus does not change even when the search concerns thousands of individuals; as the FISC has reasoned, when "one individual

${ }^{26}$ Mark R. Brown, Foreword to the Sullivan Lecture Essay: Is Privacy on Life Support?, 44 CAP. U. L. ReV. 671, 675 (2016).

27 See United States v. Miller, 425 U.S. 435, 442-43 (1976) (bank records); Smith v. Maryland, 442 U.S. 735, 744-46 (1979) (information provided to telephone service providers).

28 DONOHUE, supra note 2, at 120-21; see also Alex Kozinksi \& Eric S. Nguyen, Has Technology Killed the Fourth Amendment?, 2011-2012 CATO SuP. CT. REV. 15, 29 (observing that, "[i]f speaking to friends, putting money in a bank account and making telephone calls routed through a phone company waive the privacy of information so disclosed, then very little indeed can remain private").

29 ACLU v. Clapper, 959 F. Supp. 2d 724, 730 (S.D.N.Y. 2013).

30 Id. at 752. 
does not have a Fourth Amendment interest, grouping together a large number of similarly-situated individuals cannot result in a Fourth Amendment interest springing into existence ex nihilo." 31

"These analyses," Donohue contends, "turn a blind eye to the ways in which the privacy interests" affected by the use of the technology available when the courts adopted the third-party doctrine "have changed as technology has advanced and new analytical tools have come into being. The interests that the Court confronted in the 1970s are different than those that characterize third-party information today." Moreover, today-unlike in the pre-digital days, when law enforcement sought information disclosed to a third party by a particular person of interest-the bulk information collection programs are not predicated on the suspicion that even one of the many thousands of individuals whose information is captured-possibly you, me, or someone we know - was "engaged in [any] wrongdoing." 32

As Donohue urges, now is the time to reconsider the third-party doctrine. ${ }^{33}$ At least one member of the Supreme Court agrees: in her concurring opinion in United States $v$. Jones, the case involving the constitutionality of law enforcement attaching a GPS tracking device to an automobile, Justice Sonya Sotomayor ventured that "it may be necessary to reconsider the premise that an individual has no reasonable expectation of privacy in information voluntarily disclosed to third parties[.]" Further, she declined, in the circumstances of the case, to assume "that all information voluntarily disclosed to some member of the public for a limited purpose is, for that reason alone, disentitled to Fourth Amendment protection." 34

Of course, just because commentators have concluded the premises underlying the third-party doctrine should be revisited, and just because one Justice of the Supreme Court appears to agree, does not mean change in respect to foreign intelligence surveillance is imminent. Clapper provided an opportunity to reconsider the doctrine in the foreign intelligence context, but in overturning the district court's determination that the government's bulk metadata collection program was legal, the Second Circuit Court of Appeals ruled on statutory, not constitutional grounds. ${ }^{35}$ More recently, in Carpenter v. United States, the Supreme Court held that the third-party doctrine does not apply to cell site location data, because

31 In re FBI, No. BR 13-109, 2013 WL 5741573, at *2 (FISC Aug. 29, 2013).

32 DONOHUE, supra note 2, at 122.

33 See DonOHUE, supra note 2, at 123-24; see also Lawrence Friedman, Commonwealth v. Augustine and the Future of the Third-Party Doctrine, 41 NEW ENG. J. ON CRIM. \& CIV. CONFINEMENT 271, 283-84 (2015).

34 United States v. Jones, 565 U.S. 400, 417-18 (2012) (Sotomayor, J., concurring).

35 See ACLU v. Clapper, 785 F.3d 787, 813 (2d Cir. 2015). 
individuals have a reasonable expectation of privacy in this information. ${ }^{36}$ The Court notably confined the reach of this holding, however, to the "rare case" in which the quantity and quality of the information conveyed to a third party places it beyond the rationale in Smith. ${ }^{37}$

Unless and until the Court specifically relies upon the reasoning of Carpenter in the national security context, the government likely will continue to argue that individuals have no reasonable expectation of privacy in information incidentally and routinely captured through foreign intelligence surveillance-notwithstanding that, with this information, the most intimate details of many individuals' lives could be mapped.

Even assuming the Court extended Carpenter to protect information shared through modern telecommunicative means, still the collection of information pursuant to $\S 215$ of FISA could be justified and constitutional under the so-called "special needs" exception to the Fourth Amendment's requirements of probable cause and a warrant. This exception allows certain governmental searches absent any quantum of individualized suspicion. The Supreme Court adopted the special needs exception in response to perceived governmental interests in ensuring human health and safety in certain contexts-public policy goals that the Court distinguished from ordinary law enforcement interests. ${ }^{38}$ The classic example of a special need is the sobriety checkpoint. The checkpoint illustrates the signature feature of the exception: it applies in situations in which the government seeks to learn just one piece of information about many individuals engaged in a particular activity-say, whether any of them, while behind the wheel of an automobile, has been drinking alcohol in a way that might compromise their safety, or the public's-and the immediacy of the governmental interest would be thwarted by adherence to the warrant requirement. ${ }^{39}$

A 2002 decision of the Foreign Intelligence Surveillance Court of

36 138 S.Ct. 2206 (2018).

37 Id.

38 See Skinner v. Railway Labor Executives' Ass'n, 489 U.S. 602, 620 (1989) (holding that the government interest "in regulating the conduct of railroad employees to ensure safety, like its supervision of probationers or regulated industries, or its operation of a government office, school, or prison" presents "special needs' beyond normal law enforcement" (quotation omitted)).

39 See Michigan Dep't of State Police v. Sitz, 496 U.S. 444, 455 (1990) (holding the checkpoint program consistent with Fourth Amendment given "the State's interest in preventing drunken driving, the extent to which [the] system can reasonably be said to advance that interest, and the degree of intrusion upon individual motorists who are briefly stopped"); see also City of Indianapolis v. Edmond, 531 U.S. 32, 41-42 (2000) (holding unconstitutional a checkpoint program designed to interdict illegal narcotics, a goal indistinguishable from efforts "to uncover evidence of ordinary criminal wrongdoing"). 
Review (the FISCR) - that Court's first published decision-suggested that the Fourth Amendment exempts from the warrant requirement foreign intelligence surveillance. ${ }^{40}$ Then, in a 2008 decision, the FISCR concluded the special needs exception justified a program requiring communications service providers to assist the government in foreign intelligence acquisition related to individuals outside the United States, including U.S. persons. ${ }^{41}$

Donohue notes that the special needs exception functions in practice to authorize limited general warrants-limited, that is, by the circumstances justifying the particular search, which must be distinct from ordinary law enforcement; and by the scope of the invasion of privacy, which must be minimal. ${ }^{42}$ Given these parameters-and accepting for the moment the constitutionality of the special needs exception-it is not immediately obvious that the exception applies to any kind of bulk data collection program given the quantity and detail of the information these programs collect. ${ }^{43}$ Indeed, the FISCR concluded the exception applies despite the fact that the pieces of information acquired by the government, when assembled, could very nearly describe a person's entire life-with whom she most often spoke, where she lived, when and where she traveled, and what she purchased. A record of our days can be constructed from metadata. ${ }^{44}$ In another context, the government will use metadata as the basis for targeting drone strikes. ${ }^{45}$

At bottom, doctrinal developments like the third-party doctrine and the special needs exception not only fail to reflect accurately the Fourth Amendment's animating spirit, they cannot be confined to the criminal context: Fourth Amendment law is transsubstantive, "equally [applicable] to suspected drug dealers and suspected terrorists." 46 Thus, the diminishment of reasonable expectations of privacy and development of exceptions to the warrant requirement in criminal cases may be deployed by the government as it defends the current foreign intelligence surveillance regime and its substantial domestic component.

40 In re Sealed Case, 310 F.3d 717, 719-20 (FISA Ct. Rev. 2002).

41 In re Directives [Redacted] Pursuant to Section 105b of the Foreign Intelligence Surveillance Act, 551 F.3d 1004, 1006, 1011 (FISA Ct. Rev. 2008).

42 See DONOHUE, supra note 2, at 145-46.

43 See OWEN FISS, Warrantless Wiretapping, in A WAR LIKE NO OTHER 251 (Trevor Sutton ed., 2015) (arguing that special FISA wiretaps do not satisfy the conditions necessary for a legitimate special need).

44 See id. at 39-40.

45 David Cole, 'We Kill People Based on Metadata', NYR DAILY (May 10, 2014), https://perma.cc/KR32-GYFJ (quoting General Michael Hayden, former director of the CIA and NSA).

46 William J. Stuntz, Local Policing After the Terror, 111 YALE L.J. 2137, 2140 (2002). 
[Vol. 52 | 1

And yet: rules like the third-party doctrine and special needs exception streamline the application of the Fourth Amendment in the lower courts, by deterring both a contextual approach to expectations of privacy in the digital age and more probing explorations of the reasonableness of highyield searches of electronic communications conducted without individualized suspicion. Absent these doctrines, many lower courts likely would deploy a case-by-case approach, which could lead, potentially, to contradictory judicial orders, or orders that undermine legitimate law enforcement-and foreign intelligence surveillance-efforts. It is not too much to say that the influence of the precedent cases under the third-party doctrine and special needs exception is most keenly felt in the lower courts, where the challenges to various aspects of FISA orders inevitably have and for the most part will continue to reside.

To be sure, as against the influence of precedent, there is the argument that privacy protections the Supreme Court understands the Fourth Amendment to encompass may wax and wane as the times dictate. ${ }^{47}$ Just as lower crime rates may lead courts to reject the government's privacydiminishing arguments in criminal cases, a decrease in the threat of foreign-based terrorism may do the same in cases involving foreign intelligence surveillance. But this is not really how doctrinal development works in practice. Prosecutors in state and federal courts regularly press judges to accept arguments that will effectively shrink reasonable expectations of privacy or expand the special needs exception. Should a court disagree with the government, the status quo will prevail-in other words, there will not be a net increase in the amount of information privacy each of us enjoys, just no further decrease. And the government will be back another day to try again, armed with new arguments-and, in the context of foreign intelligence surveillance, with the traditional deference the courts have shown the policymaking of the political departments.

\section{The Problem of Deference}

The second reason why we should not expect the Supreme Court to embrace an understanding of the Fourth Amendment that prizes the individual's interest in information privacy, at least when it comes to foreign intelligence surveillance, relates to the deference the Court traditionally has shown the political branches when it comes to national security. The FISCR may have been wrong, as Donohue maintains, to recognize a foreign intelligence exception to the Fourth Amendment's

47 See id. at 2154-55. 
warrant requirement, ${ }^{48}$ but that doesn't mean the Supreme Court would not agree with its decision, or with the FISCR's general understanding of the Fourth Amendment. Indeed, history demonstrates that the judiciary may lack the institutional capacity to enforce constitutional information privacy norms in the national security context-a context in which judicial decision-making often seems to be driven by a kind of institutional anxiety.

Supreme Court deference to the political branches in the national security context has been well documented. As the legal scholar David Rudenstine has concluded, "the Court has been excessively deferential to the executive branch of government in legal disputes that the executive claims implicate national security[.]" ${ }^{\prime 9} \mathrm{He}$ emphasizes the excessive nature of this deference, going on to catalogue the array of cases in which such deference has prevailed,

including such matters as challenges to surveillance activities, restrictions on expression, infringements on political associations, kidnapping and torture policies, preventative detention practices, policies that discriminate on the basis of religion or ethnicity that result in detention and harsh treatment, or secret Army experiments that cause irreparable harm to members of the armed services. ${ }^{50}$

Consider a couple of federal rulings in post-September 11 cases in which the government asserted a national security rationale to justify rules that impinged upon legitimate First Amendment interests. In North Jersey Media Group v. Ashcroft, ${ }^{51}$ the plaintiffs objected on First Amendment grounds to the closing of certain immigration hearings deemed to be of special interest by the Department of Justice. The U.S. Court of Appeals for the Third Circuit accepted the government's argument that immigration hearings were not traditionally open proceedings and that the potentially negative consequences of open hearings trumped the right of access by the press. 52 The court claimed to recognize "the dangers presented by deference to the executive branch when constitutional liberties are at stake, especially in times of national crisis, when those liberties are likely in greatest jeopardy," but, on balance, it could not agree that openness played "a positive role in special interest deportation hearings at a time when our nation [was] faced with threats of such profound and unknown

48 See DONOHUE, supra note 2, at 145 (observing that "[t]he U.S. Supreme Court has never recognized such an exception" (emphasis added)).

49 David Rudenstine, The Age of Deference: The Supreme Court, National SECurity, AND THE CONSTITUTIONAL ORDER 3 (2016).

$50 \mathrm{Id}$.

51308 F.3d 198 (3d Cir. 2002).

52 See id. at 225. 
dimension." 53

More recently, in Holder v. Humanitarian Law Project, ${ }^{54}$ the Supreme Court ruled against the Humanitarian Law Project, which sought to assist certain groups to resolve their conflicts peacefully-including groups that the United States regarded as terrorist organizations. The Court agreed such assistance qualified as speech for First Amendment purposes, but nonetheless concluded that it ran afoul of the compelling governmental interest in preventing material aid to terrorist organizations, because such assistance could work to "legitimate" terrorist organizations, thereby freeing up resources for terrorist activities. ${ }^{55}$ Writing for the majority, Chief Justice Roberts noted that, in respect to the Humanitarian Law Project's work, "Congress and the Executive [were] uniquely positioned to make principled distinctions between activities that will further terrorist conduct and undermine United States foreign policy, and those that will not." 56

The Roberts Court has a well-earned reputation for its expansive view of freedom of speech. ${ }^{57}$ If deference prevails in cases in which free speech interests run up against national security concerns, it seems unlikely that privacy interests will fare better in similar circumstances. Notwithstanding Justice Sandra Day O'Connor's admonition in Hamdi v. Rumsfeld that a state of war is not a blank check, 58 it's worth remembering that the more representative judicial treatment of national security policy is Korematsu $v$. United States, ${ }^{59}$ a case in which a majority of all-too-human judges could not muster the will to challenge the constitutionally suspect national security claims of the political departments. ${ }^{60}$

53 Id. at 220. The U.S. Court of Appeals for the Sixth Circuit reached the opposite conclusion on similar facts in Detroit Free Press v. Ashcroft, 303 F.3d 681, 684 (6th Cir. 2002).

54 Holder v. Humanitarian Law Project, 561 U.S. 1, 2 (2010).

55 Id. at 36-37.

56 Id. at 35

57 See Marcia Coyle, The Roberts Court: the Struggle for the CONSTitution 324 (2013) (noting the First Amendment is "an area of law fast becoming identified with the Roberts Court").

58542 U.S. 507, 536 (2004) (plurality).

59323 U.S. 214 (1944).

60 Writing for the majority in Korematsu, Justice Hugo Black held the exclusion order aimed at Japanese-American citizens constitutional because the nation was at war with Japan,

because the properly constituted military authorities feared an invasion of our West Coast and felt constrained to take proper security measures, because they decided that the military urgency of the situation demanded that all citizens of Japanese ancestry be segregated from the West Coast temporarily, and finally, because Congress, reposing its confidence in this time of war in our military leaders-as inevitably it must-determined that they should have the power to do just this. There was evidence of 
For the better part of a century, justices of the Supreme Court have believed-and acted on the belief-that deference is necessary in matters touching national security. Rudenstine suggests a host of reasons that might explain such deference. It may flow, for example, from the view that the Court lacks the institutional competence "to assess matters implicating national security," ${ }^{61}$ or the view that "the judicial process is totally inappropriate for making decisions that affect national security operations," 62 or the view that our "governing scheme" has not vested the Court "with responsibility over such matters, or because [the justices]... resist having any responsibility for a decision affecting the nation's security." 63 All of these reasons also may apply, and with greater force, to the lower court judges who hear cases in which national security policy is in tension with individual rights.

Regardless of the reasons underlying the deference, the result is the same: "the legal doctrines that insulate the executive in cases implicating national security[,]" Rudenstine explains, "have expanded incrementally over many decades, gathering precedent after precedent in support of the mindset that in turn further insulates the mindset from a reexamination of its premises." 64 That mindset stands as a substantial obstacle, in the foreign intelligence surveillance context, to federal judicial reorientation of the Fourth Amendment around the privacy values the Framers sought to protect.

\section{Protecting the ReMnants OF Privacy}

So here we are: Fourth Amendment rules developed in the criminal context, like the third-party doctrine and the special needs exception, together with the Court's traditional deference to the political branches in national security matters, have led to limits on foreign intelligence surveillance that, in Donohue's view, are looser than the Fourth Amendment demands. Her suggested remedy is judicial adoption of Fourth Amendment doctrinal analyses informed by the history of opposition to general warrants that she recounts in The Future of Foreign Intelligence. For the reasons I have explained here, it seems unlikely that the federal courts will be the wellspring of such an effort.

disloyalty on the part of some, the military authorities considered that the need for action was great, and time was short.

Id. at 223-24.

61 RUDENSTINE, supra note 49, at 294.

62 RudenstiNe, supra note 49, at 298.

63 RUDENSTINE, supra note 49, at 298.

64 RUDENSTINE, supra note 49 , at 307. 
It is possible, though, that advocates might gain some traction in state courts. Freed of the obligation to follow federal precedent when interpreting their own constitutions, state courts in criminal cases can consider in a different light the balance between privacy and security with which the federal courts have struggled. Indeed, many state courts have sought to address the meaning of the protection against unreasonable searches and seizures in cases involving telecommunications technologies new and old. ${ }^{5}$ Such efforts acknowledge the need to protect from arbitrary government intrusion the interest in information privacy that the framers understood to be crucial to the exercise of liberty.

State constitutional litigation has provided an alternative path to securing individual rights for decades. ${ }^{66}$ But with the goal in mind of influencing the U.S. Supreme Court's understanding of the scope of the protection against unreasonable searches and seizures, state constitutional decisions valuing information privacy as against government action cannot be seen merely as ends unto themselves. Rather, state decisions exploring new doctrinal approaches should be seen as supporting historical, philosophical and practical arguments about the importance of information privacy-arguments with which the Supreme Court ultimately must reckon. Consider, in this light, same-sex marriage litigation in state courts: after less than a decade, there existed a sufficient mass of state precedent exploring the ways in which same-sex marriage prohibitions violated constitutional equality norms that a U.S. Supreme Court consideration of the issue under the Fourteenth Amendment had become inevitable. ${ }^{67}$

At best, in other words, state constitutional litigation will provide advocates a foothold, a body of decisions on the value of information privacy of sufficient weight that it cannot be ignored by the Supreme Court-whether in a criminal case testing the limits of the government's ability to investigate or, should a plaintiff be found to have standing, a case challenging the scope of the government's foreign intelligence surveillance regime. ${ }^{68}$ And in the cases in which it must confront state court interpretations of parallel constitutional provisions, the Supreme Court

65 See, e.g., Commonwealth v. Augustine, 4 N.E.3d 846, 850 (Mass. 2014) (noting that the state's constitution protects an individual's reasonable expectation of privacy in cellular telephone cell location data); State v. Hunt, 450 A.2d 952, 957 (N.J. 1982) (noting that the state's constitution protects an individual's reasonable expectation of privacy in telephone numbers dialed).

66 See Robert F. Williams, The LAW OF AMERicAn State CONSTITUTIONS 114-15 (2009) (discussing the "new judicial federalism").

67 See id. at 283 (discussing state constitutional precursors to federal litigation over the constitutionality of same-sex marriage).

68 See Clapper v. Amnesty International, 568 U.S. 398, 420 (2013) (holding plaintiff lacked standing to challenge certain provisions of FISA). 
will at least be pressed to explain why the Fourth Amendment should be understood to provide citizens less protection than many of its state counterparts.

Donohue is right-we need a new approach to implementing the Fourth Amendment, one that better reflects its animating purposes. ${ }^{69}$ Many state high courts have already begun to develop alternative ways of understanding the constitutional protection against unreasonable searches and seizures. These decisions may help to persuade the U.S. Supreme Court that judicially-enforceable limits on the federal government's ability to abridge individual privacy interests are as necessary today as they were when the framers sought to put an end to general warrants.

69 DonOHUE, supra note 2, at 157. 